\title{
Extra-clausal constituents in Functional Discourse Grammar: function and form
}

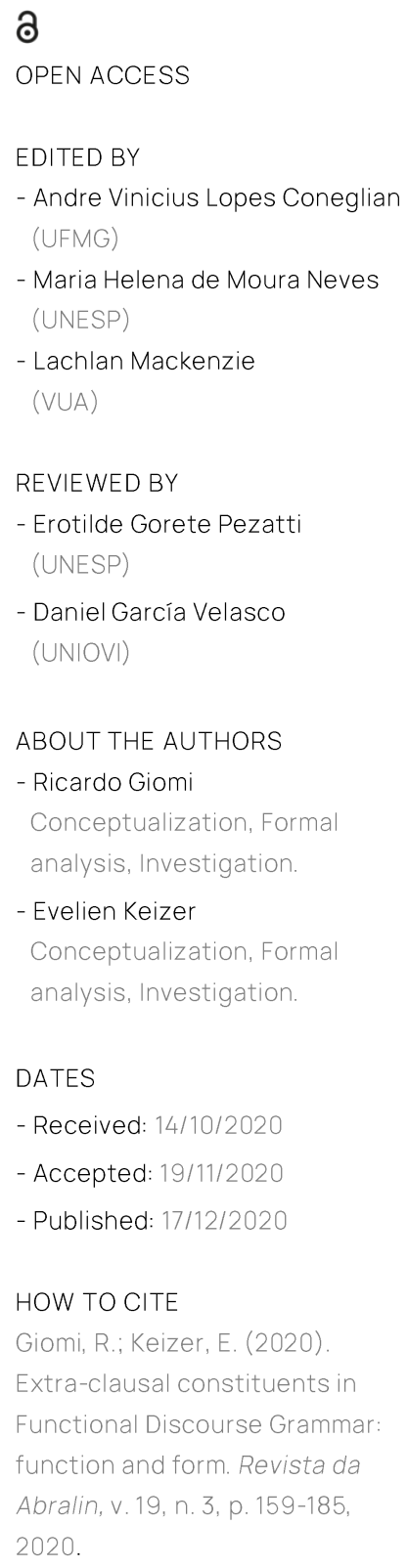

Riccardo GIOMI (D)

CELGA-ILTEC, University of Coimbra (UC)

\section{Evelien KEIZER (D)}

University of Vienna (UNIVIE)

\section{ABSTRACT}

This paper presents a first outline of an encompassing account of extraclausal constituents (ECCs) within the framework of Functional Discourse Grammar (FDG). Drawing primarily on English corpus data, we investigate both the functional and the formal properties of this heterogeneous class of constituents, focusing in particular on their underlying pragmatic structure and contribution to the ongoing discourse, and on the communicative factors relevant to their placement within the larger linguistic expressions within which they occur. More specifically, we suggest that each ECC forms a separate, though invariably dependent unit of communicative behaviour (i.e. a Subsidiary Discourse Act). Moreover, we argue that the mechanism governing the placement of ECCs vis-à-vis both their hosts and each other is fundamentally different from the placement rules proposed in FDG for morphosyntactic units belonging to the clause, phrase or word; the result is a system that captures both the functional constraints on the placement of ECCs and their greater positional freedom.

\section{RESUMO}

O artigo apresenta um primeiro esboço de uma abordagem abrangente aos constituintes extra-oracionais (CEOs) no quadro da Gramática Discursivo-Funcional (GDF). Baseando-nos principalmente em dados de corpus do inglês, investigamos as propriedades funcionais e formais desta classe 


\section{REVISTA DA ABRALIN}

de constituintes heterogénea, focando em particular a sua estrutura pragmática subjacente e a sua contribuição para o desenvolvimento do discurso, bem como os fatores comunicativos que determinam seu posicionamento dentro dos enunciados em que ocorrem. Mais especificamente, propomos que cada CEO forma uma unidade de comportamento comunicativo separada, se bem que invariavelmente dependente (i.e., um Ato Discursivo Secundário). Além disso, defendemos que o mecanismo que regula o posicionamento dos CEOs face à unidade comunicativa principal que eles acompanham e a outros CEOs é basicamente diferente das regras de posicionamento propostas pela GDF no que toca a unidades morfossintáticas que pertencem à oração, ao sintagma ou à palavra. O resultado é um sistema que catura tanto as restrições funcionais sobre o posicionamento dos CEOs como a maior liberdade posicional de que gozam estes constituintes em comparação com os que pertencem a camadas mais baixas da organização morfossintática.

\section{KEYWORDS}

Extra-clausal constituents. Functional Discourse Grammar. Word order rules. Subsidiary Discourse Acts. Rhetorical functions.

\section{PALAVRAS-CHAVE}

Constituintes extra-oracionais. Gramática Discursivo-Funcional. Regras de ordem das palavras. Atos Discursivos Secundários. Funções retóricas.

\section{Introduction}

Although theoretical accounts of extra-clausal constituents (ECCs) go back several decades (e.g. HAEGEMAN, 1991; DIK, 1997a; 1997b), it is only in recent years that their importance in everyday communication has come to be fully appreciated, leading to a surge of studies on this broad group of expressions. Much of this research stresses the peripheral status of these elements, relegating them to the domain of communicative competence. Studies on grammaticalization and pragmaticalization, for instance, often regard extra-clausal expressions serving discourse-related functions as being external to the grammar proper (see DEGAND; EVERS-VERMEUL, 2015 for an overview). Similarly, Discourse Grammar (e.g. KALTENBÖCK et al., 2011; HEINE et al., 2013) distinguishes between a Sentence Grammar and a Thetical Grammar, to deal with intra- and extra-clausal relations, respectively. 


\section{REVISTA DA ABRALIN}

Functional Discourse Grammar (FDG: HENGEVELD; MACKENZIE, 2008), does not accept this distinction. For FDG, what determines which expressions belong to the grammatical component is not their intra- or extra-clausal status, but whether their pragmatic and semantic content receives explicit, systematic encoding in language structure. This means that any aspect of the speaker's communicative intention that is morphosyntactically or phonologically expressed in a language is dealt with within the grammar. This does not mean that FDG does not acknowledge the specific functional and formal features of ECCs - it certainly does, but within the grammar, by modelling their distinctive properties at all levels of grammatical analysis (pragmatics, semantics, morphosyntax and phonology).

Nevertheless, no full account of ECCs is as yet available within FDG. Although the theory provides a sophisticated system of rules for the placement of morphosyntactic constituents at the layers of Clause, Phrase and Word, no such mechanism exists for the highest morphosyntactic layer in FDG, that of the Linguistic Expression. A first attempt to formulate such rules will be presented in Section 3. Before we do so, however, we need to address the tricky question of what exactly qualifies as an ECC and how these elements may be characterized from an FDG perspective. These questions will be addressed in Section 2: in Section 2.1 we will show that the criteria for identifying ECCs proposed so far are vague and often contradictory; in Section 2.2 we will demonstrate how the distinctive features of FDG allow for a more precise and consistent characterization of this heterogeneous group of elements. First, however, we will provide a brief sketch of the overall organization of the FDG model, and its functional approach to the linear placement of constituents.

\section{Functional Discourse Grammar: a brief introduction}

\subsection{General characterization}

Functional Discourse Grammar has been characterized as a "structural-functional" theory of language (BUTLER, 2003, p. 30), in that "it seeks to reconcile the patent fact that languages are structured complexes with the equally patent fact that they are adapted to function as instruments of communication between human beings" (HENGEVELD; MACKENZIE, 2008, p. ix). The result is "a form-oriented function-to-form" model: it is "function-to-form" in that it starts with the Speaker's communicative intention and ends with the articulation of a linguistic expression, and "form-oriented" in only representing those pragmatic and semantic phenomena that are systematically reflected in the morphosyntactic and phonological form of an utterance (e.g. HENGEVELD; MACKENZIE, 2008, p. 39-40).

In FDG, linguistic expressions are analysed at four independent levels of representation, capturing their discourse-pragmatic, semantic, morphosyntactic and phonological aspects. The levels are hierarchically organized in such a way that pragmatics is taken to govern semantics, pragmatics and 


\section{REVISTA DA ABRALIN}

semantics to govern morphosyntax, and pragmatics, semantics, and morphosyntax to govern phonology. The privileged role of pragmatics is further reflected in the fact that in FDG the basic unit of analysis is not the clause (a morphosyntactic unit) but the Discourse Act (a communicative unit).

As shown in Figure 1, the Grammatical Component of FDG interacts, within a wider theory of verbal interaction, with a Conceptual Component, containing a speaker's pre-linguistic communicative intention; a Contextual Component, which hosts information about those aspects of the immediate discourse context that affect the form of a linguistic utterance; and an Output Component responsible for the production of spoken, signed or written forms.

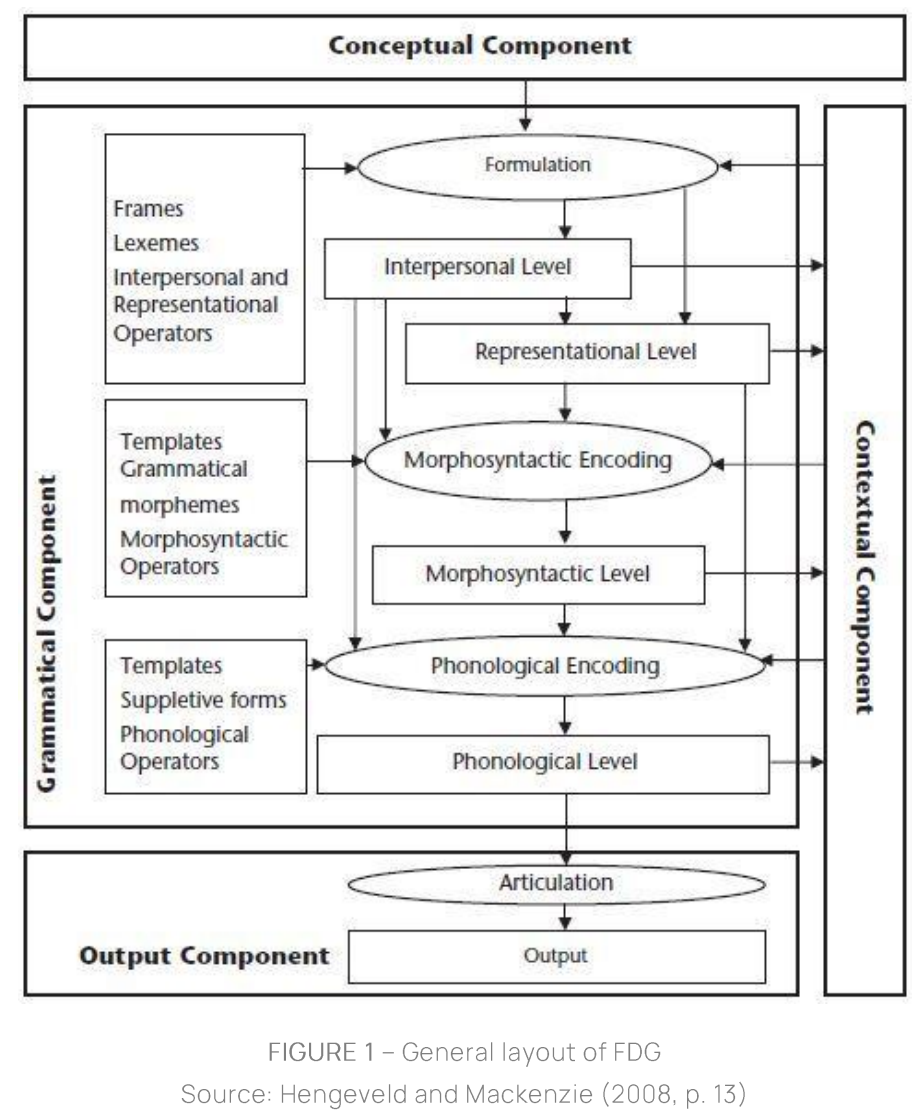

\subsection{Four levels of analysis}

The four levels of representation used in FDG are the outcome of two separate operations. Starting from the top, the first operation is that of Formulation, which deals with all the meaningful elements of a linguistic expression. This operation results in representations at the higher two levels of analysis, the Interpersonal and Representational Levels. The second operation, that of Encoding, subsequently takes care of an expression's formal properties, and leads to representations at the 


\section{REVISTA DA ABRALIN}

Morphosyntactic and Phonological Levels. Each of these four levels is hierarchically organized into a number of different layers.

The highest level of representation, the Interpersonal Level, deals with "all the formal aspects of a linguistic unit that reflect its role in the interaction between the Speaker and the Addressee" (HENGEVELD; MACKENZIE, 2008, p. 46). The most inclusive layer at this level is that of the Move (M), which serves as "an autonomous contribution to an ongoing interaction" (HENGEVELD; MACKENZIE, 2008, p. 50). Each Move consists of one or more Discourse Acts (A), "the smallest identifiable units of communicative behaviour", which, unlike Moves, "do not necessarily further the communication in terms of approaching a conversational goal" (KROON, 1995, p. 85; HENGEVELD; MACKENZIE, 2008, p. 60). Examples of Moves consisting of more than one Discourse Act are given in (1) and (2) (HENGEVELD; MACKENZIE, 2008, p. 53):

(1) a. A: What happened yesterday in the Scottish Premier League?

B: Celtic won. And Rangers lost.

b. $\quad\left(M_{\mathrm{I}}:\left[\left(\mathrm{A}_{\mathrm{I}}:-\right.\right.\right.$ Celtic won- $\left.\left(\mathrm{A}_{\mathrm{I}}\right)\right)\left(\mathrm{A}_{\mathrm{I}}:-\right.$ Rangers lost- $\left.\left.\left.\left(\mathrm{A}_{\mathrm{J}}\right)\right)\right]\left(\mathrm{M}_{\mathrm{I}}\right)\right)$

(2) a. Watch out, because there will be trick questions in the exam.

b. $\left(\mathrm{M}_{\mathrm{I}}:\left[\left(\mathrm{A}_{\mathrm{I}}:-\right.\right.\right.$ watch out- $\left.\left.\left.\left(\mathrm{A}_{\mathrm{I}}\right)\right)\left(\mathrm{A}_{\mathrm{J}}:- \text { there will be trick questions in the exam- }\left(\mathrm{A}_{\mathrm{J}}\right)\right)_{\text {Motiv }}\right]\left(\mathrm{M}_{\mathrm{I}}\right)\right)$

In (1), the Speaker gives equal communicative status to each of the two Discourse Acts, resulting in a relation of equipollence. In (2) we have a relation of dependence, i.e. a relation between a Nuclear and a Subsidiary Discourse Act: the Subsidiary Discourse Act is therefore assigned a rhetorical function (here the function of Motivation, since the Subsidiary Discourse Act provides the Speaker's reasons for uttering the Nuclear Discourse Act).

Discourse Acts, in turn, maximally consist of an Illocution (F), the Speech Participants ( $\mathrm{P}_{1}$ and $\mathrm{P}_{2}$, representing the Speaker and the Addressee) and a Communicated Content (C), which "contains the totality of what the Speaker wishes to evoke in his/her communication with the Addressee" (HENGEVELD; MACKENZIE, 2008, p. 87). Within the Communicated Content, one or more Subacts of Reference (R) and Ascription (T) are performed by the Speaker. Each of these layers is provided with a slot for operators and modifiers, providing additional grammatical and lexical information, respectively, about the layer in question. A sentence like (3a) would thus be given the representation in (3b):

(3) a. They unfortunately resigned yesterday.

b. $\left(\mathrm{A}_{\mathrm{I}}:\left[\left(\mathrm{F}_{\mathrm{I}}\right.\right.\right.$ : $\left.\operatorname{DECL}\left(\mathrm{F}_{\mathrm{I}}\right)\right)\left(\mathrm{P}_{\mathrm{I}}\right)_{\mathrm{S}}\left(\mathrm{P}_{\mathrm{J}}\right)_{\mathrm{A}}\left(\mathrm{C}_{\mathrm{I}}:\left[\left(\mathrm{T}_{\mathrm{I}}\right)_{\mathrm{FOC}}\left(+\mathrm{id} \mathrm{R}_{\mathrm{I}}\right)\left(+\mathrm{id} \mathrm{R}_{\mathrm{J}}\right)\right]\left(\mathrm{C}_{\mathrm{I}}\right):\left(\mathrm{D}_{\mathrm{I}}\right.\right.$ : unfortunately $\left.\left.\left.\left.\left(\mathrm{D}_{\mathrm{I}}\right)\right)\left(\mathrm{C}_{\mathrm{I}}\right)\right)\right]\left(\mathrm{A}_{\mathrm{I}}\right)\right)$

Within the Declarative Discourse Act $\left(\mathrm{A}_{\mathrm{I}}\right)$, the Communicated Content consists of two Subacts of Reference, one evoking the entity referred to as they $\left(\mathrm{R}_{\mathrm{I}}\right)$ and the other one evoking the temporal entity described as yesterday $\left(\mathrm{R}_{\mathrm{J}}\right)$, as well as a Subact of Ascription, evoking the property 'resign' $\left(\mathrm{T}_{\mathrm{I}}\right.$, 


\section{REVISTA DA ABRALIN}

which in this particular case is assigned the pragmatic function Focus). Both Subacts of Reference are specified by the operator +id, indicating the Speaker assumes the Addressee to be able to identify the referent evoked. Finally, the Communicated Content is modified by the attitudinal adverb unfortunately, here represented as heading a Lexical Deed $\left(\mathrm{D}_{\mathrm{I}}\right)^{1}$

The second level of Formulation, the Representational Level, deals with the semantic aspects of a linguistic expression, i.e. with those aspects of a linguistic expression that reflect the way in which language relates to the extra-linguistic world it describes. The units at this level thus represent the different linguistically relevant types of entities in the extra-linguistic world (HENGEVELD; MACKENZIE, 2008, p. 131). The highest layer at this level is that of the Propositional Content (p), which represents a mental construct which can be evaluated in terms of its truth. The Propositional Content consists of one or more Episodes (ep), i.e. sets of States-of-Affairs (e) that are coherent in terms of time, space and participants. Each State-of-Affairs (e) is, in turn, characterized by a Configurational Property $\left(\mathrm{f}^{\mathrm{c}}\right)$, consisting typically of a lexical (typically verbal) Property $\left(\mathrm{f}^{\mathrm{l}}\right)$ and one or more arguments, typically headed by a nominal lexical property $\left(f^{1}\right)$. Here, too, each layer is provided with a slot for operators and modifiers. A Representational Level analysis of the sentence in (3a) above is provided in (4):

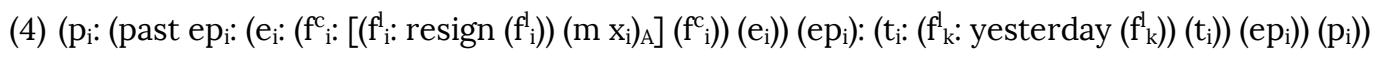

Here the Propositional Content $\left(\mathrm{p}_{\mathrm{i}}\right)$ contains a single Episode $\left(\mathrm{ep}_{\mathrm{i}}\right)$, which in turn consists of a single State-of-Affairs $\left(\mathrm{e}_{\mathrm{i}}\right)$. This State-of-Affairs is headed by a Configurational Property $\left(\mathrm{f}_{\mathrm{i}}^{\mathrm{c}}\right)$, consisting of the verbal Property resign $\left(\mathrm{f}_{\mathrm{i}}^{\mathrm{i}}\right)$ and its argument (the Individual they, represented as $\mathrm{x}_{\mathrm{i}}$ ). The representation further contains a modifier (the time-denoting element yesterday, $\mathrm{t}_{\mathrm{i}}$, modifying the Episode), and two operators: 'past' at the layer of the Episode, and plurality (' $m$ ') at the layer of the Individual. Finally, the argument $\left(\mathrm{x}_{\mathrm{i}}\right)$ is provided with the semantic (macro-)role of Actor (A).

The output of the operation of Formulation forms the input to the operation of Encoding; at this stage, it is no longer possible to add any meaning components to the utterance. At the first level of Encoding, the Morphosyntactic Level, the largest unit of analysis is that of the Linguistic Expression (Le), which typically contains one or more Clauses. Clauses (Cl), in turn, may consist of one or more Phrases and Words, as well as of other Clauses. Phrases may contain one or more Words, as well as other Phrases or Clauses. ${ }^{2}$ Phrases and Words are further categorized on the basis of the kind of head they have; thus there are Verbal Phrases (Vp) and Verbal Words (Vw), Nominal Phrases (Np) and Nominal Words (Nw), etc. Finally, it is at this level that the syntactic functions Subject and Object are assigned. A morphosyntactic analysis of the sentence in (3a) is given in (5):

\footnotetext{
${ }^{1}$ Following Giomi (2020) Lexical Deeds are used for the representation of lexical elements at the Interpersonal Level, performing the communicative act of specifying or modifying another interpersonal unit by lexical means.

${ }^{2}$ Words consist of one of more Morphemes; these are not included in the analyses given in this paper.
} 


\section{REVISTA DA ABRALIN}

(5) $\left(\mathrm{Le}_{\mathrm{i}}:\left(\mathrm{Cl}_{\mathrm{i}}\right.\right.$ : $\left[\left(\mathrm{Np}_{\mathrm{i}} \text { : }\left(\mathrm{Nw}_{\mathrm{i}} \text { : they }\left(\mathrm{Nw}_{\mathrm{i}}\right)\right)\left(\mathrm{Np}_{\mathrm{i}}\right)\right)_{\text {Subj }}\left(\operatorname{Advp}_{\mathrm{i}}\right.\right.$ : unfortunately $\left.\left(\mathrm{Advp}_{\mathrm{i}}\right)\right)\left(\mathrm{Vp}_{\mathrm{i}}\right.$ : $\left(\mathrm{Vw}_{\mathrm{j}}\right.$ : resigned $\left.\left.\left(\mathrm{Vw}_{\mathrm{j}}\right)\right)\left(\mathrm{Vp}_{\mathrm{i}}\right)\right)\left(\mathrm{Np}_{\mathrm{j}}:\left(\mathrm{Nw}_{\mathrm{i}}:\right.\right.$ yesterday $\left.\left.\left.\left.\left.\left(\mathrm{Nw}_{\mathrm{i}}\right)\right)\left(\mathrm{Np}_{\mathrm{j}}\right)\right)\right]\left(\mathrm{Cl}_{\mathrm{i}}\right)\right)\left(\mathrm{Le}_{\mathrm{i}}\right)\right)$

Finally, the Phonological Level converts the input from the three higher levels into phonological form. Once again the layers at this level are hierarchically organized. The highest layer, the Utterance (U), consists of one or more Intonational Phrases (IP), which in turn consist of Phonological Phrases (PP). ${ }^{3}$ A possible (simplified) phonological representation of example (3a) is given in (6). This representation contains one operator, ' $\mathrm{f}$ ', indicating a falling intonation at the layer of the Intonational Phrase (triggered by the presence of a Declarative Illocution at the Interpersonal Level).

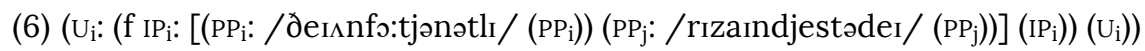

\subsection{Linear ordering in FDG}

1.3.1. Ordering at the layer of the Clause

In order to account for the possibilities of and restrictions on the linear ordering of elements within the Clause, ${ }^{4}$ FDG offers a set of, to some extent language specific, placements rules. These rules are functionally-inspired in that the placement of constituents is (almost) entirely determined by information contained in the two Formulation levels, with elements being placed in a top-down, outsideto-inside manner (HENGEVELD; MACKENZIE, 2008, p. 310-316; KEIZER, 2015, p. 184-191); in other words, units from the Interpersonal Level are placed before units from the Representational Level, and, within each level, units from hierarchically higher (outer) layers before units from lower (inner) layers.

Hengeveld and Mackenzie (2008, p. 311-312) suggest that for the placement of clausal constituents, languages make use of one or more (up to four) absolute positions. English, for instance, has three absolute positions: an initial $\left(\mathrm{P}^{\mathrm{I}}\right)$, a medial $\left(\mathrm{P}^{\mathrm{M}}\right)$ and a final $\left(\mathrm{P}^{\mathrm{F}}\right)$ position. As soon as one of these positions is filled, one or two relative positions can be created (e.g. $\left.\mathrm{P}^{\mathrm{M}+1}, \mathrm{P}^{\mathrm{F}-1}\right)$. In order to illustrate how the placement rules apply, consider the following (rather contrived but grammatical) example:

(7) She will luckily probably meet him again next week.

\footnotetext{
${ }^{3}$ PPs in turn divide into Phonological Words, which are made up of Feet, which contain Syllables; these are not included in the representations given here.

${ }^{4}$ Similar rules apply to the Phrase and the Word; in what follows, however, we will restrict ourselves to the placement of clausal elements.
} 


\section{REVISTA DA ABRALIN}

As the only interpersonal modifier, the adverb luckily (modifying the Communicated Content) is the first element to be placed in one of the three absolute positions, ending up in position $\mathrm{P}^{\mathrm{M}}$. The adverb probably, as the highest representational modifier (scoping over the Propositional Content), is the next element to be placed, going to the newly created position $\mathrm{P}^{\mathrm{M}+1}$. Subsequently, the modal auxiliary will (expressing an operator at the layer of the Episode) is placed in $\mathrm{P}^{\mathrm{M}-1}$, the Episode modifier next week in clause-final position $\left(\mathrm{P}^{\mathrm{F}}\right)$, and the frequency adverb again in the pre-final position $\left(\mathrm{P}^{\mathrm{F}-1}\right)$. Finally, the main verb, subject and object and are placed in positions $\mathrm{P}^{\mathrm{M}+2}, \mathrm{P}^{\mathrm{I}}$ and $\mathrm{P}^{\mathrm{M}+3}$, respectively.

$\begin{array}{llllllll}\text { (8) } \mathrm{P}^{\mathrm{I}} & \mathrm{P}^{\mathrm{M}-1} & \mathrm{P}^{\mathrm{M}} & \mathrm{P}^{\mathrm{M}+1} & \mathrm{P}^{\mathrm{M}+2} & \mathrm{P}^{\mathrm{M}+3} & \mathrm{P}^{\mathrm{F}-1} & \mathrm{P}^{\mathrm{F}} \\ \text { she } & \text { will } & \text { luckily } & \text { probably } & \text { meet } & \text { him } & \text { again } & \text { next week }\end{array}$

\subsubsection{Ordering at the layer of the Linguistic Expression}

In strong contrast to this highly detailed system for the linear placement of clausal elements, very little has been said in FDG about the placement of elements at the layer of the Linguistic Expression. At this layer, Hengeveld and Mackenzie (2008, p. 312) distinguish three positions, labelled pre-clausal $\left(\mathrm{P}^{\mathrm{Pre}}\right)$, clausal $\left(\mathrm{P}^{\mathrm{Centre}}\right)$ and post-clausal $\left(\mathrm{P}^{\mathrm{Post}}\right)$, as shown in $(9):^{5}$

$\begin{array}{llllll}\text { (9) Linguistic Expression: } & \mathrm{P}^{\text {Pre }} & \mid & \mathrm{P}^{\text {Centre }} & \mid & \mathrm{P}^{\text {Post }} \\ \text { Clause: } & & \mid \mathrm{P}^{\mathrm{I}} & \mathrm{P}^{\mathrm{M}} & \mathrm{P}^{\mathrm{F}}\end{array}$

As for the kind of elements that may fill the extra-clausal positions, Hengeveld and Mackenzie (2008, p. 313) observe that interpersonal modifiers prefer the pre-clausal position. In that case, the hierarchically-driven rules illustrated above apply: in (10), the highest interpersonal element, the illocutionary adverb honestly, goes to pre-clausal position, and the next highest element, the reportative adverb reportedly, to clause-medial position.

$$
\begin{array}{clll}
\text { (10) } \mathrm{P}^{\text {Pre }} \quad \mathrm{P}^{\mathrm{I}} & \mathrm{P}^{\mathrm{M}} & \ldots \\
\text { Honestly, } & \text { she } & \text { reportedly } & \text { has been drinking again. }
\end{array}
$$

In addition, extra-clausal positions may be filled by Subsidiary Discourse Acts: in (11) the Orientational Discourse Act as for his ideas takes the pre-clausal position, while in (12) the Corrective Discourse Act his ideas goes to post-clausal position (HENGEVELD; MACKENZIE, 2008, p. 55-56):

\footnotetext{
${ }^{5}$ Note that the central position may also be filled by elements smaller than the Clause (as in A: Who wrote this? B: Peter, my brother.). For the sake of simplicity, however, we will retain the terms pre-clausal and post-clausal.
} 


\section{REVISTA DA ABRALIN}

(11) $\mathrm{P}^{\text {Pre }} \quad \mathrm{P} \mathrm{P}^{\text {Centre }}$

As for his ideas, I don't like them.

(12) $\mathrm{P}^{\text {Centre }} \quad \mathrm{P} \mathrm{P}^{\text {Post }}$

I don't like them, his ideas.

Subsidiary Discourse Acts may, however, also interrupt the Nuclear Act, as in the case of nonrestrictive relative clauses, which are analysed as Subsidiary Discourse Acts with the rhetorical function Aside (HENGEVELD; MACKENZIE, 2008, p. 58, 284):

(13) The game, which began at 7.30, ended in a draw.

$\left(\mathrm{M}_{\mathrm{I}}\right.$ : $\left[\left(\mathrm{A}_{\mathrm{I}}\right.\right.$ :-the game ended in a draw- $\left.\left.\left.\left(\mathrm{A}_{\mathrm{I}}\right)\right)\left(\mathrm{A}_{\mathrm{J}}:- \text { which began at } 7.30\left(\mathrm{~A}_{\mathrm{J}}\right)\right)_{\text {Aside }}\right]\left(\mathrm{M}_{\mathrm{i}}\right)\right)$

At the Phonological level, the Subsidiary Discourse Act, as well as both segments of the Nuclear Discourse Act, correspond to separate Intonational Phrases. At the Morphosyntactic Level, however, the two Discourse Acts are assumed to integrate syntactically (into a single Noun Phrase), by applying the general mould for (restrictive and non-restrictive) relative clauses (HENGEVELD; MACKENZIE, 2008, p. 284).

In what follows, however, we prefer to analyse these Asides as ECCs at the Morphosyntactic Level. This means that we need to distinguish a third extra-clausal position, the Interpolated position $\left(\mathrm{P}^{\mathrm{Int}}\right)$, which hosts all extra-clausal elements that interrupt the Clause. Strong support for this analysis comes from the fact that recognizing an Interpolated position is unavoidable given the placement rules operating at the layer of the Clause (KEIZER, 2020a, p. 114). Consider the position of the (lexicalized) reporting clause so they say in (14):

(14) John had frequently, so they say, insulted her.

If the interpersonal element so they say were to be assigned a position within the Clause, it would have to go to the absolute position $\mathrm{P}^{\mathrm{M}}$, since, according to the hierarchical placement rules, it would be the first element to be assigned a position (and it clearly does not occupy $\mathrm{P}^{\mathrm{I}}$ or $\mathrm{P}^{\mathrm{F}}$ ). This, however, turns out to be impossible: if so they say were to go to $\mathrm{P}^{\mathrm{M}}$, then the auxiliary had, expressing the Episode operator Past, and as such the second element to be placed, would have to go to the relative position $\mathrm{P}^{\mathrm{M}-1}$. In (15), however, the position preceding so to say is already taken by the hierarchically lower State-of-Affairs modifier frequently. The only logical conclusion is that so they say is not part of the Clause at all, as, in fact, signalled by its prosodic non-integration (indicated here by the presence of commas). Instead, it goes to a third extra-clausal position, the "interpolated position" ( $\mathrm{P}^{\mathrm{Int}}$ ); in that case, the clausal constituents had and frequently can take the clausal positions $\mathrm{P}^{\mathrm{M}}$ and $\mathrm{P}^{\mathrm{M}+1}$, respectively (KEIZER, 2020a, p. 114): 


\section{REVISTA DA ABRALIN}

$\begin{array}{lllllll}\text { (15) } \mathrm{P}^{\mathrm{I}} & \mathrm{P}^{\mathrm{M}} & \mathrm{P}^{\mathrm{M}+1} & \mathrm{P}^{\text {Int }} & \mathrm{P}^{\mathrm{M}+2} & \mathrm{P}^{\mathrm{M}+3} \\ \text { John } & \text { had } & \text { frequently } & \text { so they say } & \text { insulted } & \text { her }\end{array}$

Hengeveld and Mackenzie do mention some factors determining the placement of elements in one of the extra-clausal positions, but do not offer a systematic account of the placement of ECCs or any general principles governing the internal organization of the extra-clausal positions (or fields). We will come back to this issue in Section 3. Before we do so, however, we need to have a closer look at the question of what qualifies as an ECC.

\section{What qualifies as an ECC?}

\subsection{Previous approaches}

\subsubsection{Formal properties of ECCS}

Dik (1997a; 1997b) was one of the first functional linguists to propose a systematic account of the functional and formal properties of ECCs. Most of the prototypical features of ECCs identified by Dik are in fact still maintained in more recent functionally-oriented work on the subject, e.g. in Discourse Grammar (KALTENBÖCK et al., 2011; HEINE et al. 2013) or in Haselow's (2016) "macrogrammar". As regards the formal properties of ECCs, Dik (1997a, p. 310-311; 1997b, p. 104-105, 197, 379ff.) mentions the following features:

(16) a. "[ECCs] either occur on their own, or are typically set off from the clause proper by breaks or pause-like inflections in the prosodic contour; they are 'bracketed off' from the clause by such prosodic features".

b. "They are never essential to the internal structure of the clause with which they are associated; when they are left out, the clause still forms an integral whole".

c. "They are not sensitive to the grammatical rules which operate within the limits of the clause, although they may be related to the clause by rules of coreference, parallelism, and antithesis"; "They are rather loosely associated with the clause, and cannot easily be described in terms of clause-internal rules and principles".

d. "[They] are in general more difficult to subordinate than intraclausal elements".

e. ECCs can occur on the following four positions: (i) absolute or free-standing, (ii) preclausal, (iii) parenthetical, (iv) post-clausal; and although "[s]ome ECCs are by their very 


\section{REVISTA DA ABRALIN}

function tied to one of these positions", "others may occur, with much the same function, in any two, three, or all four of them". ${ }^{6}$

As far as syntax is concerned, (16) provides quite an extensive list of typical properties of ECCs. Nevertheless, it will be clear that these properties are very general and rather vague. Property (16b), for instance, does not only apply to ECCs, but also to clausal and phrasal adjuncts (whose omission never results in grammatical ill-formedness), while property (16e) should at least be phrased in relative terms, i.e. that elements have greater mobility when used as ECCs than when they occur as clausal elements (e.g. That was a mistake, probably vs. *That was a mistake probably - where the comma indicates a prosodic break). In addition, the way (16e) is formulated suggests that this property only refers to some ECCs, or at least applies differently to different types of ECCs. Clearly, the same may be said of properties (16a) and (16d), which are explicitly presented as strong tendencies and not as necessary features of ECCs.

That the properties in (16) are not sufficient diagnostics of extra-clausality is in fact recognized by Dik himself when he observes that these properties do not always "provide an unequivocal answer to the question whether a given constituent occurs outside or inside the clause" (1997b, p. 383). In the very same passage, however, the author also claims that "this question can be satisfactorily answered in most cases", thus implicitly suggesting that the best way to identify ECCs is to consider each instance individually. As we shall see in Section 2.2, most of the formal properties mentioned in (16) are, in fact, useful, but only when applied to specific types of ECCs. An exception in this respect is the property of prosodic non-integration, which is a strong indicator of extra-clausal status, irrespective of the type of ECC in question, in the sense that any constituent which is not prosodically integrated in the expression it accompanies is almost certainly syntactically independent. As is well-known, however, prosodic non-integration is often harder to establish than syntactic nonintegration (as defined by the criteria in (16b-e)), especially because, due to purely articulatory phenomena such as rate of speech, the distinctive phonological properties of ECCs are not always clearly reflected in phonetic realization. In other words, prosodic non-integration is a strong indicator, but not a necessary feature, of ECC status (see DEHÉ, 2007, 2014).

Despite the increase in studies dedicated to ECCs, subsequent functionally-oriented research does not seem to have added much to Dik's formal characterization of ECCs. More formally-based approaches, on the other hand, have traditionally suggested more specific tests for establishing the syntactic non-integration of a constituent. Among the criteria most often invoked are the impossibility of clefting or questioning an ECC, as well as the fact that ECCs do not fall within the scope of negators, proforms, quantifiers and ellipses (e.g. QUIRK et al., 1985, p. 612-631; PULLUM; HUDDLESTON, 2002, p. 575-576; HUDDLESTON et al., 2002, p. 1350-1362). The longest list of such tests to our knowledge can be found in Espinal (1991), who proposes no fewer than fifteen criteria to

\footnotetext{
${ }^{6}$ Unlike Dik, we will not regard free-standing, "holophrastic" expressions as ECCs: with respect to what would a summons (e.g. Hey), greeting (e.g. Hello) or vocative (e.g. Bert!) be "external", when occurring in isolation?
} 


\section{REVISTA DA ABRALIN}

distinguish between clausal and extra-clausal constituents, including such additional properties as the (non-)existence of restrictions on consecutio temporum, the (im)possibility of filling an argument slot, and the question of whether the constituent can trigger subject-verb inversion in V2 languages.

Now, as argued by Keizer (2018; 2020b), some of these properties of ECCs are essentially the syntactic reflexes of more fundamental functional properties, in particular of the fact that, as we will also see below, all ECCs are by necessity non-restrictive/non-truth-conditional. Thus, clefting, questioning and pronominalization/negation/ellipsis can only be successfully applied to elements that are part of the (extended) predication (and as such of the proposition), i.e. to truth-conditional elements. It is no surprise, then, that it is precisely these tests that give the most consistent results and can be applied to the largest variety of ECCs. As regards the strictly syntactic tests that have been proposed in the literature, their main limitation is that they are either only relevant to specific languages (e.g. subject-verb inversion in V2 languages) or to specific syntactic types of ECCs (e.g. the non-application of consecutio temporum rules, which obviously only concerns ECCs that contain a verb form), or indeed to both of the preceding (e.g. the possibility of omitting the relative pronoun in English restrictive relative clauses but not in non-restrictive ones, ESPINAL, 1991, p. 732).

All of this does not, however, mean that purely syntactic tests for extra-clausality are not useful. An important reason why none of these tests provides a definitive criterion, in fact, is the structural diversity of the expressions that may function as ECCs. This limitation is acknowledged by Espinal (1991, p. 729), who also observes that "[n]ot all of the tests apply uniformly to all disjuncts, so it may be fruitful, in future research, to attempt to develop a detailed typology of disjunct constituents". Such typologies have indeed subsequently been proposed (e.g. KALTENBÖCK, 2007 for English parentheticals), which makes it possible to establish exactly which tests are or are not relevant to each specific type of ECCs. By applying this method, some of the syntactic criteria which have been put forth in the literature may indeed turn out to be necessary and/or sufficient for at least some types of ECCs. As a result, the diagnostic power of these tests will be greatly enhanced compared to a methodology which does not discriminate between different syntactic types of ECCs. In addition, the specific assumptions of a particular linguistic theory may provide the analyst with more specific criteria: even if such criteria may not be acceptable for linguists of other theoretical persuasions, they can at least lead to internally consistent and operationally effective accounts of the syntactic properties of ECCs. An example of such a theory-specific criterion was given in Section 1.3.2, where it was shown that the set of functionallybased rules for syntactic placement postulated by FDG may be invoked as a useful indicator of intraor extra-clausal status in the context of this specific framework.

2.1.2. Functional properties of ECCs

According to Dik (1997b, p. 383ff.), ECCs fulfil one (or more) of four major clusters of discourse functions: 


\section{REVISTA DA ABRALIN}

(17) (i) Interaction management: e.g. greetings (Hello), leave-takings (Goodbye), summonses (Hey there), addresses (John!), minimal responses (yes, no, okay).

(ii) Attitude specification, e.g. expressives (Ouch! Damnit!, Hurray!).

(iii) Discourse organization:

a. Boundary marking: initiators (hey, by the way), "push-and-pop" markers (e.g. the discourse-oriented uses of but/'cause and so, respectively, see Hengeveld and Mackenzie (2008, p. 51-52)), finalizers (okay, how about you, anyway).

b. Orientation: ECCs that serve to "[anchor] each new contribution to the discourse $[\ldots]$ in the discourse representation as built up so far". Orientational ECCs are divided into those with the discourse functions Theme, Condition and Setting (providing temporal, spatial and/or other information).

c. Tail: "adjoined constituents which add bits of information which may be relevant to a correct understanding of the clause".

(iv) Discourse execution: "those ECCs which play a role in the expression of the actual content of the discourse", e.g. full responses, response initiators (e.g. well) and tags.

The purpose of Dik's typology of ECCs is essentially descriptive, and from this point of view, the classification he offers is again quite exhaustive, in the sense that most naturally occurring ECCs can unproblematically be classified as belonging to one of the four general types distinguished. From a theoretical viewpoint, however, some aspects of this taxonomy are no longer tenable in FDG. Most importantly, from the perspective adopted in this study, it is crucial that semantic notions like Condition and (temporal or spatial) Setting be kept separate from strictly interpersonal ones such as that of discourse organization, rather than being subsumed under the latter, as in Dik's classification. Organizing discourse, in our view, is an inherently metacommunicative activity: true discourse-organizing devices are those that express rhetorical relations between linguistic units such as Discourse Acts (or parts thereof), e.g. first and foremost, in addition, to conclude, I mean, briefly, by the way, etc. By contrast, specifying the conditions under which an event takes place, or the temporal, spatial or other circumstances relevant to that event, is not a matter of discourse organization (in the sense just defined): such relations do not hold between units of discourse but between events in the real world, that is, they concern the denotational properties of linguistic utterances. This does not mean that a conditional, temporal or circumstantial phrase or clause may not also play a role in the structuring of discourse, for instance by serving as an Orientation for the following Discourse Act: it is, however, a fundamental tenet of FDG that these two dimensions of linguistic analysis must be clearly distinguished from each other, by capturing semantic/descriptive relations at the Representational Level and discursive/rhetorical ones at the Interpersonal Level.

As in the case of the formal properties of ECCs discussed in the previous section, the bulk of Dik's functional classification is maintained in most later work on the topic. For instance, Kaltenböck et al. (2011, p. 861-862) characterize the meanings of theticals as being "shaped by the entire situation of discourse" (original emphasis), which in turn is described as a "network of components" including 


\section{REVISTA DA ABRALIN}

the three macro-functions in (17i-iii), as well as a number of additional components: (a) the specification of the source of the information, (b) the immediate discourse setting of the ongoing interaction and (c) any longer-term encyclopaedic knowledge "presumed to be shared by the interlocutors" that may be relevant to the interpretation of the utterance. From a strictly descriptive point of view, these concepts may be regarded as useful additions to Dik's classification of ECCs. From a more operationally-oriented perspective, however, the functions (or meaning components) identified by Dik (1997b) and Kaltenböck et al. (2011) can hardly be used as heuristics for extra-clausal status. This is mainly because a great many constituents that are - or, at least, can be - part of a larger clause can also serve one or more of these functions (e.g. titles like Mr or Mrs, or adverbs like kindly, as used in requests, for interaction management; evaluative adverbs like rightly or wrongly for attitude specification; various types of conjunctions and sentence connectives for discourse organization; reportative adverbs or auxiliaries for the source of the information; any kind of deictic expression for discourse setting, etc.).

Importantly, Kaltenböck et al.'s (2011) six components of the "situation of discourse" are presented as an attempt to capture the invariably non-restrictive character of the meaning of theticals /ECCs, a semantic property of ECCs which has been frequently emphasized in the literature (see Keizer (2018; 2020a; 2020b) and references given there). However, although non-restrictive meaning does indeed appear to be a universal property of ECCs, in the sense that they never restrict the extension of their host, it has also been stressed that there is no one-to-one relation between semantic non-restrictiveness and syntactic non-integration. In fact, just like the various components of the "situation of discourse" themselves, non-restrictiveness is by no means an exclusive property of ECCs. This becomes evident when one considers such pairs of sentences as (18a-b), from Dutch (a V2 language): while the attitudinal adverb helaas ('unfortunately') is in both cases non-restrictive in meaning, subject-verb inversion is obligatory in (18a) (where the adverb is prosodically integrated) but impossible in (18b) (where the adverb is prosodically independent). This clearly indicates that this constituent is syntactically integrated in the clause in the former case, while functioning as an ECC in the latter.

$\begin{array}{llllllll}\text { (18) a. } & \text { Helaas } & \text { vond } & \text { ik } & \text { de } & \text { film } & \text { nogal saai. } \\ & \text { unfortunately } & \text { found } & \text { I } & \text { the } & \text { film } & \text { rather boring } \\ \text { b. Helaas, } & \text { ik } & \text { vond } & \text { de } & \text { film } & \text { nogal saai. } \\ & \text { unfortunately } & \text { I } & \text { found } & \text { the } & \text { film } & \text { rather boring }\end{array}$

Thus, contrary to what is often assumed (see e.g. Fraser (1996, p. 169-170) on truthfully), there is no straightforward correspondence between non-restrictive use and extra-clausal status, nor between restrictive use and clausal status. Rather, as we will argue in the next section, extra-clausality can in most cases only be explained with reference to the particular discourse function of the constituent in question, more specifically with regard to its status as a separate unit of communicative 


\section{REVISTA DA ABRALIN}

behaviour (a separate Discourse Act in FDG), related to, but crucially not part of, the expression it precedes, follows or interrupts.

\subsection{Defining ECCs in FDG}

2.2.1. ECCs as Subsidiary Discourse Acts: definition

In this section we will offer a syntactic definition of ECCs in terms of their position outside the clausal template at the Morphosyntactic Level (see Section 1.3.2). It will be clear, however, that the "function-to-form" nature of the model, and in particular the functionally-inspired placement rules of FDG, dictate that the extra-clausal status of these constituents is triggered by some aspect of their interpersonal and/or representational analysis. We therefore propose that the extra-clausal status of an expression at the Morphosyntactic Level is a reflection of its status as a Subsidiary Discourse Act at the Interpersonal Level. ${ }^{7}$ In addition, a Discourse Acts analysis of these expressions also - independently - leads to their default representation as separate Intonational Phrases at the Phonological Level. On such an approach, the formal (syntactic and prosodic) features of an expression may serve as a diagnostic for its extra-clausal status; the explanation for these features can, however, only be provided in terms of the expression's interpersonal, discourse-pragmatic function.

Naturally, analysing all ECCs as separate Discourse Acts at the Interpersonal Level raises a number of questions, first and foremost what it means for an element to function as a (Subsidiary) Discourse Act. Recall from Section 1.2 that in FDG Discourse Acts are defined as "the smallest identifiable units of communicative behaviour"; Subsidiary Discourse Acts, in addition, depend for their proper interpretation on the presence of a Nuclear Discourse Act. Moreover, as we have seen, each Discourse Act is characterized by the presence of an Illocution. In most cases, this Illocution has an abstract head, resulting in the conventionalized morphosyntactic and/or prosodic expression of declarative, interrogative, imperative (etc.) Illocution. While this is clearest in those cases where the ECC takes the form of a Clause, as in (19a), non-clausal ECCs, such as Orientations, can also have their own illocutionary force, as illustrated in (19b), and are indeed already analysed as separate Discourse Acts in FDG. The same applies to vocatives like Steve in (19c), which have an interpellative Illocution:

(19) a. Once this happens, remove pan from heat (be sure to wear oven mitts!) and stir in the pretzels immediately. ( $\mathrm{COCA}^{8}$, newspaper)

\footnotetext{
${ }^{7}$ The expressions dealt with in this paper are all dependent on the presence of a host expression; as such they will be analysed as Subsidiary Discourse Acts. Expressions such as interjections or vocatives can, however, also be used independently (as a free-standing or equipollent Discourse Act); a discussion of these uses is, however, beyond the scope of this paper.

${ }^{8}$ The Corpus of Contemporary American English. http://corpus.byu.edu/coca/. Accessed 2020.
} 


\section{REVISTA DA ABRALIN}

b. My brother? I promise not to betray him. (cf. HENGEVELD; MACKENZIE, 2008, p. 55)

c. Well, somebody has to do that work, Steve. (COCA, spoken) ${ }^{9}$

Illocutions can, however, also take a lexical head, as in the case of performative verbs, interjections and social formulas (HENGEVELD; MACKENZIE, 2008, p. 69-78); in those cases, the lexeme (or rather the Lexical Deed it heads) is regarded as the direct expression of the illocutionary force of the Discourse Act (see below). Whenever these expressions are used in combination with a Nuclear Discourse Act, as in (20), they will be given the interpersonal status of Subsidiary Discourse Acts, which in turn triggers their realization as ECCs.

(20) a. It sounds like you have either Classic mail (yuck), or the new Beta Mail (double yuck) (COCA, web)

b. I totally respect the work that you had to put in to do that, and I think that you have a beautiful, gorgeous voice, so congratulations. (COCA, TV)

In addition, however, we would like to argue that many elements that have so far been analysed as modifiers can also plausibly be regarded as Subsidiary Discourse Acts, as, for instance, in the following examples, where interpersonal frankly and I hear, as well as representational quickly and very, very slowly behave as separate communicative units, with their own illocutionary force (KEIZER, 2018; 2020a; 2020b):

(21) a. And I hope this works out for him, frankly. (COCA, spoken)

b. You come from a big family, I hear. (COCA, movie)

(22) a. Quickly, you have to help my husband. (COCA, TV)

b. And so, unlike my siblings, who were racing through books, I read slowly - very, very slowly. (COCA, spoken)

Finally, we would like to extend our analysis to also include elements that, when functioning as grammatical operators or rhetorical-function markers, are (syntactically and prosodically) integrated in the Clause; these, too, can be used to make their own separate contribution to the discourse, in which case they will be realized as ECCs. Cases in point are so, now and well (the latter only in its mitigating use):

(23) a. We still have something. Now, let's build from here. (COCA, newspaper)

\footnotetext{
${ }^{9}$ Unlike in these examples, ECCs serving as comments tend to have the same Illocution as the Nuclear Discourse Act. Still, even in such cases, this is not a strict requirement, as combinations of different Illocutions do occur - e.g. Though such a move would make Dish exactly zero dollars, it will (hopefully?) stanch the number of viewers who decide to jump ship for a different cable provider (COCA, magazine).
} 


\section{REVISTA DA ABRALIN}

b. As for romance, well, over-achievers usually don't have room for that (COCA, web)

It is not difficult to see that an analysis of ECCs as Subsidiary Discourse Acts can account for all the functional and formal properties of ECCs provided in the literature. As for their function, the ECCs in (19)-(23) clearly perform one (or more) of the typical functions of ECCs identified by Dik (1997b) and Kaltenböck et al. (2011) (see Section 2.1.2 above).

Moreover, as separate Discourse Acts, these expressions cannot, at the Representational Level, be part of the Propositional Content(s) corresponding to the Nuclear Discourse Act; they are therefore, by definition, non-truth-conditional (non-restrictive) with regard to the proposition(s) expressed in the Nuclear Discourse Act. As we have seen, this explains some of the syntactic properties typically associated with ECCs, such as the fact that they cannot be clefted or questioned, and fall outside the scope of (predication) pronominalization, negation and ellipsis (see Section 2.1). The same is true for other syntactic properties, such as their failure to trigger consecutio temporum (which requires an element to be part of the SoA or Episode), the fact that they cannot function as arguments (which requires an element to be part of the Configurational Property), and, of course, the fact that they are (semantically as well as syntactically) optional.

As far as the purely syntactic criteria are concerned, one important consequence of the analysis of ECCs as separate Discourse Acts is that their linear placement is not subject to the usual placement rules for clausal constituents. This accounts for the fact that they (generally speaking) have a higher degree of positional mobility, as evidenced by the fact that they can occur in linear positions which had they been part of the clausal template - would not have been available (see Section 1.3.2, example (15)). This also explains why they can interrupt the complement of any verb, even if this complement corresponds to a low layer (see also KEIZER, 2018; 2020b). In (24), for instance, the verb continue takes a Configurational Property as its complement (HENGEVELD; MACKENZIE, 2008, p. 263-265); as such it cannot contain the illocutionary adverb frankly (which modifies a higher, interpersonal layer). However, as soon as this adverb functions as a separate Discourse Act, it will occur in an extra-clausal position, which is available irrespective of the kind of complement involved. ${ }^{10}$

(24) And then the leisure elements in Charlotte continue to, frankly, outperform many other markets ... (Internet, Charlotte Business Journal)

The fact that Subsidiary Discourse Acts are not sensitive to the hierarchically defined placement rules for clausal elements is a crucial feature of all types of ECCs. Other syntactic criteria, however, are only relevant to specific types of ECC, e.g. the impossibility to leave out (non-subject) relative pronouns (which only applies to relative clauses) or the fact that ECCs do not trigger subject-verb

\footnotetext{
${ }^{10}$ Note that, if syntactically and prosodically integrated, frankly in this position can only be interpreted as a manner adverb, an interpretation that is highly unlikely in (24).
} 


\section{REVISTA DA ABRALIN}

inversion in V2 languages (which is only relevant to elements that can conceivably go to the clauseinitial position).

Finally, an analysis of ECCs as separate Discourse Acts also explains why they are typically prosodically non-integrated. Discourse Acts, we have seen, have their own illocutionary force, which is often expressed prosodically; this leads to a default relation between Discourse Acts at the Interpersonal Level and Intonational Phrases at the Phonological Level (see HANNAY; KROON, 2005; HENGEVELD; MACKENZIE, 2008, p. 432). This default relation may, of course, be overridden in both directions. Thus, not all separate IPs correspond to separate Discourse Acts (IP status can, for instance, also be triggered by pragmatic factors, like the presence of emphasis, or by syntactic factors such as weight/complexity), while Discourse Acts need not always correspond to full IPs (as in the case of syntactically light elements, especially in rapid speech, and deaccented expressions). ${ }^{11}$ Having said that, there are many cases in which speakers have to rely on prosodic non-integration for the coding of extra-clausal status. For instance, if one were to judge from linear order only, the adverbial very slowly in (25) could in principle also be in a clause-internal position $\left(\mathrm{P}^{\mathrm{F}}\right)$ : it is only the prosodic realization of the adverbial that clearly indicates that this constituent is an extra-clausal one:

(25) "Let us retreat, very slowly," said Spar. (COCA, fiction)

\subsubsection{ECCs as Subsidiary Discourse Acts: analysis}

If, as we suggest, extra-clausal status at the Morphosyntactic Level is triggered by the Subsidiary Discourse Act status of the corresponding unit at the Interpersonal Level, this raises the question of what the internal structure of these Discourse Acts looks like. In some cases, their representation is quite straightforward. Thus, for ECCs with a lexically specified Illocution, such as performatives, interjections and social formulas, we can simply adopt the analysis proposed by Hengeveld and Mackenzie (2008), the difference being that, when used as Subsidiary Discourse Acts, these elements need to be assigned a rhetorical function. In the case of the interactive expression so congratulations in (20b), this would lead to the following representation (where the Subsidiary Discourse Act is regarded as elaborating the Nuclear Discourse Act):

$$
\text { (26) }\left(\mathrm{A}_{\mathrm{I}}:\left[\left(\mathrm{F}_{\mathrm{I}}:\left(\mathrm{D}_{\mathrm{I}} \text { : congratulations }\left(\mathrm{D}_{\mathrm{I}}\right)\right)\left(\mathrm{F}_{\mathrm{I}}\right)\right)\left(\mathrm{P}_{\mathrm{I}}\right)_{\mathrm{S}}\left(\mathrm{P}_{\mathrm{J}}\right)_{\mathrm{A}}\right]\left(\mathrm{A}_{\mathrm{I}}\right)\right)_{\text {Elaboration }}
$$

Similarly unproblematic is the analysis of ECCs with representational content, such as Orientations or Asides, which can simply be represented as Discourse Acts with an abstract Illocution and

\footnotetext{
${ }^{11}$ Such exceptions have been described in detail in studies on the relation between syntax and prosody (e.g. CRYSTAL, 1969; BOLINGER, 1989; CRUTTENDEN, 1997; GUSSENHOVEN, 2004; DEHÉ, 2007, 2014).
} 


\section{REVISTA DA ABRALIN}

a Communicated Content consisting of at least one Subact. Thus, the Subsidiary Discourse Act My brother? in (19b) will be analysed as follows:

(27) $\left(\mathrm{A}_{\mathrm{I}}:\left[\left(\mathrm{F}_{\mathrm{I}}: \operatorname{INTER}\left(\mathrm{F}_{\mathrm{I}}\right)\right)\left(\mathrm{P}_{\mathrm{S}}\right)_{\mathrm{I}}\left(\mathrm{P}_{\mathrm{A}}\right)_{\mathrm{J}}\left(\mathrm{C}_{\mathrm{I}}:\left(\mathrm{R}_{\mathrm{I}}:[\ldots]\left(\mathrm{R}_{\mathrm{I}}\right)\right)\left(\mathrm{C}_{\mathrm{I}}\right)\right)\right]\left(\mathrm{A}_{\mathrm{I}}\right)\right)_{\text {Orientation }}$

A little more challenging are those ECCs which contain interpersonal lexical information which is not expressed in the form of a Subact of Ascription. This concerns many elements that have so far always been analysed as modifiers of a particular interpersonal layer, such as finally (at the layer of the Move or the Discourse Act), frankly (at the layer of the Illocution) or unfortunately (at the layer of the Communicated Content). A representation of the modifier unfortunately was given in (3), repeated here in somewhat simplified form):

(28) a. They unfortunately resigned yesterday.

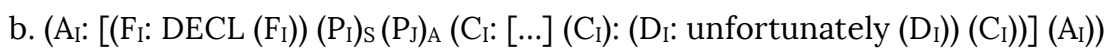

However, when these elements function as Subsidiary Discourse Act, they do not modify any interpersonal layer - they will, of course, be interpreted as commenting on a particular part of the Nuclear Discourse Act, but the element itself is not explicitly linked to any particular layer within the Nuclear Discourse Act. Since the lexical content is identical in both cases, we propose that these elements be again analysed as Lexical Deeds, but now heading the Communicated Content contained in the Subsidiary Discourse Act. For the adverb unfortunately in (29a), this would lead to the representation in (29b):

(29) a. Unfortunately, we have not learned from their experience.

b. $\left(\mathrm{A}_{\mathrm{I}}:\left[\left(\mathrm{F}_{\mathrm{I}} \text { : } \mathrm{DECL}\left(\mathrm{F}_{\mathrm{I}}\right)\right)\left(\mathrm{P}_{\mathrm{I}}\right)_{\mathrm{S}}\left(\mathrm{P}_{\mathrm{J}}\right)_{\mathrm{A}}\left(\mathrm{C}_{\mathrm{I}} \text { : }\left(\mathrm{D}_{\mathrm{I}} \text { : unfortunately }\left(\mathrm{D}_{\mathrm{I}}\right)\right)\left(\mathrm{C}_{\mathrm{I}}\right)\right)\right]\left(\mathrm{A}_{\mathrm{I}}\right)\right)_{\text {Comment }}$

Such an analysis has a number of advantages. First of all, it allows us to distinguish clearly between two different uses of the same element: as interpersonal modifiers (realized as intra-clausal elements) and as Subsidiary Discourse Acts (realized as ECCs). Secondly, since the element in question is not explicitly linked to a particular layer, this kind of analysis can be used for all interpersonal adverbs/adverbials, irrespective of the layer they belong to as modifiers. Finally, these elements differ from interpersonal dummies like bladibla, which are also analysed as heads of the Communicated Content (HENGEVELD; KEIZER, 2011, p. 1973), but which are not analysed as Lexical Deeds (GIOMI, 2020, p. 348).

This leaves us with elements such as so, now and well, which in their prosodically integrated form express operators or functions at the Interpersonal Level. When these elements are used as ECCs, such an analysis is clearly not available: firstly, because, if they express a Discourse Act by themselves, they cannot specify a layer within the Nuclear Discourse Act, and, secondly, because every Discourse Act has to contain some lexical information. Therefore, when used as ECCs, these 


\section{REVISTA DA ABRALIN}

elements must be analysed as lexemes. Given that, unlike interpersonal adverbs, they do not comment on another Discourse Act, we propose that these lexemes be represented not as lexical heads of the Communicated Content, but rather, in analogy with performatives, interjections and social formulas, as lexical heads of the Illocution. This would lead to the following representation for the element now in (23a), where the rhetorical function Connection captures the fact that now in this use establishes a link between the previous discourse and the following (Nuclear) Discourse Act:

$$
\text { (30) ( } \left.\mathrm{A}_{\mathrm{I}}:\left[\left(\mathrm{F}_{\mathrm{I}}:\left(\mathrm{D}_{\mathrm{I}} \text { : now }\left(\mathrm{D}_{\mathrm{I}}\right)\right)\left(\mathrm{F}_{\mathrm{I}}\right)\right)\left(\mathrm{P}_{\mathrm{I}}\right)_{\mathrm{S}}\left(\mathrm{P}_{\mathrm{J}}\right)_{\mathrm{A}}\right]\left(\mathrm{A}_{\mathrm{I}}\right)\right)_{\text {Connection }}
$$

In this section we have emphasized that one crucial feature of ECCs is that they are not sensitive to the hierarchically inspired placement rules for clausal elements. This leaves us with the question of what determines the - by no means random - placement of ECCs at the layer of the Linguistic Expression and the kind of placement rules needed to account for these positional preferences. This question will be addressed in the next section.

\section{The placement of extra-clausal constituents}

Although systematic accounts of the placement of ECCs, vis-à-vis their hosts or each other, seem to be lacking so far, a number of determining factors have been mentioned in the literature (e.g. DIK, 1997a; 1997; HENGEVELD; MACKENZIE, 2008; HANNAY; GÓMEZ GONZÁLEZ, 2012; KEIZER, 2020a). As mentioned in Section 1.3.2, one important factor for the placement of ECCs is the rhetorical function of the Subsidiary Discourse Act (e.g. DIK, 1997b, p. 388, 403; HENGEVELD; MACKENZIE, 2008, p. 55,56$)$. Thus, as shown in examples (11)-(12), ECCs with the function Orientation will take a preclausal position, while Corrections and Clarifications tend to follow the host. In other cases, however, the main clause and the ECC may occur in either order, their linear position reflecting the order of the corresponding Discourse Acts within the Move (as in the case of Motivations, which may either precede or follow the Nuclear Act; see HENGEVELD; MACKENZIE, 2008, p. 54).

Another important factor is that of "targeting" (see e.g. HUDDLESTON et al., 2002, p. 1351; POTTS, 2005, p. 104; BLAKEMORE, 2006, p. 1685). Thus, in accordance with the principle of domain integrity (DIK, 1997b, p. 402; HENGEVELD; MACKENZIE, 2008, p. 285), many ECCs are adjacent to the clausal constituent to which they are functionally related, as is typically the case, for instance, with appositional NPs and relative clauses.

In addition, the placement of an ECC may be the result of the informational status of the elements involved, in the sense that ECCs may be used to separate topic from comment, or to indicate emphasis or contrast. An example is given in (31), where the ECC I believe serves to emphasize the information that follows: 


\section{REVISTA DA ABRALIN}

(31) But, but, but it does not ever apply to rich people, such as Donald Trump, who got, I believe, \$14 million from his father. (COCA, spoken)

Furthermore, ECCs may function to enhance discourse coherence, as in those cases where a non-restrictive relative clause is used, not so much to provide background information (as for instance in (13) above), but rather to move the discourse forward, by providing new, salient information (e.g. HANNAY; MACKENZIE, 1996, p. 112-113). An example is given in (32), where the non-restrictive relative clause in final position not only provides additional information about the thousands of ostensibly Palestinian protesters referred to in the main clause, but in addition provides the link between the previous clause and the following one, thus lending coherence to the passage:

(32) While struggling to remain in power, the Assad regime in Syria sought to divert public anger against it by busing thousands of ostensibly Palestinian protesters to the Israeli border, who then proceeded to try to cross into the Jewish state. Jerusalem will find it necessary to station larger forces along its frontiers to defend against an array of security threats arising from the turmoil in neighboring states (COCA, academic)

This particular example also shows that several factors may be at work at the same time, and may be in competition. Thus, although targeting is a strong factor in the placement of certain ECCs, it can be overridden by the need to indicate discourse coherence. In other cases, targeting may be overridden by such production factors as incrementality and self-monitoring. An example is given (33), where we find a Correction in post-clausal rather than interpolated position (cf. (37) below for a comparable example of non-adjacent Clarification):

(33) At one point, 20 percent of our roads were impacted, our state highways, that is. (COCA, spoken)

The same (combinations of) factors are at work when more than one ECC occurs in the same extra-clausal field. In (34), the Orientation My daughter takes the leftmost position, followed by the Labelling Discourse Act Leila and the Descriptive Discourse Act who is eighteen. The order of the three pre-clausal ECCs is clearly dictated by the respective rhetorical functions: reversing the order of the proper name and the relative clause, for instance, would not be possible, while if Leila occurred before my daughter the former would be interpreted as an Orientation and the latter as either a Label or a Specification: ${ }^{12}$

\footnotetext{
${ }^{12}$ On the rhetorical functions 'Labelling', 'Specification' and 'Description' see Hannay and Keizer (2005).
} 


\section{REVISTA DA ABRALIN}

(34) My daughter, Leila, who is eighteen, she came home all excited. (COCA, spoken)

When more than one Discourse Act with the same rhetorical function co-occurs in the same field, different factors must of course be invoked to explain the relative order of the various ECCs. In (35), for instance, the crucial factor determining the placement of the two interpolated ECCs is again the principle of domain integrity (the two consecutive, elaborating non-restrictive relative clauses are adjacent to their respective targets):

(35) Claire, who is the youngest competitor in the club single by two years, got into the oversubscribed event through a lottery system, which irked her big sister, who had to sweat it out on the waiting list. (COCA web)

In (36), from Chinese, each of the three Orientational Discourse Acts progressively narrows down the macrotopic of the discourse. According to Paul and Whitman (2017, p. 12) "[d]isrupting the superset > subset ordering [...] leads to unacceptability". The reason for the ordering of the three Orientations must thus be sought in the long-term extralinguistic knowledge associated with the referents introduced in each Discourse Act, namely the arrangement of those referents along the generic/specific axis:

$\begin{array}{cllll}\text { (36) Zhōngguó, dà chéngshi, } & \text { Shànghă, jiāotōng brjiào luàn. } \\ \text { China } & \text { big city } & \text { Shanghai traffic } & \text { relatively chaotic }\end{array}$

"As for China, as for big towns, Shanghai, the traffic is rather chaotic."

In other cases, however, the order of Discourse Acts with the same rhetorical function is much freer. In (37), from French (TESNIÈRE, 1976, p. 175), all three post-clausal NPs function as Clarificational Discourse Acts:

$\begin{array}{rllllllll}\text { (37) Il la lui a donné, à Jean, son père, } & \text { sa } & \text { moto. } \\ \text { he it to-him has given to Jean his father his motorbike }\end{array}$ "He gave it to him, to Jean, his father, his motorbike."

Unlike the pronominal arguments expressed in the Nuclear Discourse Act, the three ECCs could in principle surface in any order. This indicates that their relative positions can only be explained with reference to matters of incremental language processing, which in turn is likely to be influenced by the information contained in the Contextual Component.

Summing up, the factors relevant to the placement of ECCs within the Linguistic Expression are partly grammatical in nature (rhetorical function, information structure) and partly related to context, conceptualization or language processing (e.g. targeting/domain integrity, incrementality, 


\section{REVISTA DA ABRALIN}

complexity). Although Hengeveld and Mackenzie are certainly right in arguing that interpersonal adverbials like honestly in (10) are more likely to be realized as ECCs than adverbials with representational meaning, we have argued that ECCs never express modifiers, operators or functions but always correspond to separate (Subsidiary) Discourse Acts: as such, ECCs are never part of the Nuclear Discourse Act, and therefore their position within the Linguistic Expression cannot be determined by differences in interpersonal or representational functional scope.

An important corollary of this conclusion is that the distinction between absolute and relative positions would not seem to apply to the layer of Linguistic Expressions. The reason for drawing this distinction at the layer of the Clause (and lower layers) is, in fact, precisely the fact that the order in which constituents expressing non-core elements of the Formulation levels are assigned a position at the Morphosyntactic Level is assumed to be determined by the interpersonal or representational layer to which these elements belong (see Section 1.3.1). As Hengeveld (2013, p. 15), puts it, "the place occupied by hierarchically higher constituents is crucial in deciding what the absolute positions relevant for a language are": so, if hierarchically-driven placement is irrelevant to the extra-clausal syntax, this entails that it is not possible to identify any absolute (or relative) position at the layer of Linguistic Expressions. We therefore suggest that the mechanism that governs the creation and assignment of extra-clausal positions is not one of expansion (of absolute positions by means of relative ones) but rather one whereby each extra-clausal position can be repeated indefinitely in accordance with the speaker's communicative needs. That is, whenever a Move contains more than one Subsidiary Discourse Act, the Encoder will successively create as many slots within each extraclausal field as are needed to host all the ECCs assigned to that field. Accordingly, rather than distinguishing between, say, an absolute position $\mathrm{P}^{\text {Pre }}$ and one or more relative positions $\mathrm{P}^{\mathrm{Pre+n}}$, in sequences of more than one ECC we will simply identify each slot in the relevant extra-clausal field with a separate Arabic number. For instance, the place taken by the various Clauses and Phrases in (34) and (37) will be as indicated in (38)-(39):

$$
\mathrm{P}^{\text {Pre1 }} \quad \mathrm{P}^{\text {Pre2 }} \quad \mathrm{P}^{\text {Pre3 }} \quad \mathrm{P}^{\text {Centre }}
$$

(38) My daughter, Leila, who is eighteen, she came home all excited.

$$
\mathrm{P}^{\text {Centre }} \quad \mathrm{P}^{\text {Post1 }} \quad \mathrm{P}^{\text {Post2 }} \quad \mathrm{P}^{\text {Post3 }}
$$

(39) Il la lui a donné, à Jean, son père, sa moto.

The important advantage of the notational convention introduced in (38)-(39) is that it straightforwardly reflects the differences in both the nature of clausal and extra-clausal positions and the mechanisms governing the placement of constituents in these positions. 


\section{REVISTA DA ABRALIN}

\section{Conclusions}

In this paper, we have proposed a first outline of an encompassing FDG account of ECCs. The main claims put forth are as follows:

- At the Interpersonal Level, all ECCs are analysed as Subsidiary Discourse Acts, that is, as separate units of communicative behaviour that depend for their interpretation on a discursive relation with an independent (Nuclear) Discourse Act. These relations are expressed by a restricted set of rhetorical functions (Orientation, Clarification, etc.), which can be assigned to the Subsidiary Discourse Act.

- At the Representational Level, ECCs may take several forms, but the common feature of all these expressions is that they are never restrictive/truth-conditional. This follows from the fact that, as separate Discourse Acts, they are never part of the Propositional Content(s) corresponding to the Nuclear Discourse Act.

- As the very term "extra-clausal constituent" indicates, ECCs are characterized by the fact that, at the Morphosyntactic Level, they are always external to the Clause (or other morphosyntactic unit) corresponding to the Nuclear Discourse Act. Various theory-independent syntactic tests can be applied as diagnostics for extra-clausal status, most of which are syntactic reflexes of semantic or pragmatic properties. Other, purely syntactic tests also prove to be useful, but with the proviso that, not being functionally motivated, these only apply to specific syntactic types of ECCs and/or in specific languages.

From a theory-internal FDG perspective, strong evidence for the extra-clausal status of an element is provided by the fact that the position of such elements can often not be accounted for by the hierarchically-driven placement rules that govern the linear order of constituents at the lower layers of the Morphosyntactic Level. Instead, we have proposed that the placement rules relevant for the placement of ECCs at the layer of Linguistic Expression are not informed by matters of interpersonal or representational hierarchy, but by a variety of (sometimes conflicting) grammatical and extragrammatical factors. Given the irrelevance of interpersonal and semantic hierarchy for the placement of constituents within the Linguistic Expression, we have suggested that the distinction between absolute and relative positions does not apply to this layer; accordingly, the mechanism responsible for the placement of multiple ECCs in one and the same extra-clausal field is not one of expansion but one of repetition.

- At the Phonological Level, ECCs are by default analysed as separate Intonational Phrases (even if, for shorter elements, this will not always be reflected in phonetic 


\section{REVISTA DA ABRALIN}

realization), which is explained as a direct consequence of their Discourse Act status at the Interpersonal Level.

Despite the obvious advantages of the analysis of ECCs proposed in this paper, we realize that it is, indeed, only a first outline, and that more research will be needed to justify the approach taken, especially as regards the syntax and prosody of ECCs. We do hope, however, that the hypotheses put forth in this paper will stimulate further research on this topic in the context of a discoursefunctional approach to the structure of grammar.

\section{REFERENCES}

BLAKEMORE D. Divisions of labour: the analysis of parentheticals. Lingua, v. 116, p. 1670-1687, 2006.

BOLINGER, D. Intonation and its uses. London: Arnold, 1989. 484p.

BUTLER C. S. Structure and function: a guide to three major structural-functional theories, part 1: approaches to the simplex clause. Amsterdam: John Benjamins, 2003. 573p. DOI: 10.1075/slcs.63.

CRUTTENDEN, A. Intonation. 2. ed. Cambridge: Cambridge University Press, 1997. 218p. DOI: 10.1017/CBO9781139166973.

CRYSTAL, D. Prosodic systems and intonation in English. Cambridge: Cambridge University Press, 1969. 396p.

DEGAND, L.; EVERS-VERMEUL, J. Grammaticalization or pragmaticalization of discourse markers? More than a terminological issue. Journal of Historical Pragmatics, v. 16, n.1, p. 59-85, 2015. DOI: 10.1075/jhp.16.1.03deg.

DEHÉ, N. The relation between syntactic and prosodic parenthesis. In: DEHÉ, N.; KAVALOVA, Y. (Ed.). Parentheticals. Amsterdam: John Benjamins, 2007. p. 261-284. DOI: 10.1075/la.106.15deh.

DEHÉ, N. Parentheticals in spoken English: the syntax-prosody relation. Cambridge: Cambridge University Press, 2014. 261p. DOI: 10.1017/CBO9781139032391.

DIK, S. C. The theory of Functional Grammar, part 1: the structure of the clause. 2. ed. Berlin and New York: De Gruyter Mouton, 1997a. 509p. DOI: 10.1515/9783110218367.

DIK, S. C. The theory of Functional Grammar, part 2: complex and derived constructions. Berlin and New York: De Gruyter Mouton, 1997b. 477p. DOI: 10.1515/9783110218374.

ESPINAL, T. The representation of disjunct constituents. Language, v. 67, n. 4, p. 726-762, 1991. DOI: $10.2307 / 415075$.

FRASER, B. Pragmatic markers. Pragmatics, v. 6, p. 167-190, 1996. DOI: 10.1075/prag.6.2.03fra.

GIOMI, R. Shifting structures, contexts and meanings: a Functional Discourse Grammar account of grammaticalization. 2020. 598f. Tese (Doutorado em Linguística) - Faculdade de Letras, Universidade de Lisboa. 


\section{REVISTA DA ABRALIN}

GUSSENHOVEN, C. The phonology of tone and intonation. Cambridge: Cambridge University Press, 2004. 380p. DOI: $10.1017 /$ СBO9780511616983.

HAEGEMAN, L. Parenthetical adverbials: the radical orphanage approach. In: CHIBA, S.; OGAWA, A.; FUJIWARA, Y.; YAMADA, N.; KOMA, O.; YAGI, T. (Ed.). Aspects of modern English linguistics: papers presented to Masatomo Ukaji on his 60th Birthday. Tokyo: Kaitakusya, 1991. p. 232-254.

HANNAY, M.; GÓMEZ-GONZÁLEZ, M. d. l. A. Thematic parentheticals in Dutch and English. Linguistics and the Human Sciences, v. 6, n. 1-3, p. 99-127, 2012. DOI: 10.1558/lhs.v6i1-3.99.

HANNAY, M.; KROON, C. Acts and the relationship between discourse and grammar. Functions of Language, v. 12, n. 1, p. 87-124, 2005. DOI: 10.1075/fol.12.1.05han.

HANNAY, M.; MACKENZIE, J. L. Effective writing in English: a resource guide. Groningen: Martinus Nijhoff, 1996. 385p.

HANNAY, M.; KEIZER, E. A discourse treatment of English non-restrictive nominal appositions in Functional Discourse Grammar. In: MACKENZIE, J. L.; GÓMEZ GONZÁLEZ, M. d. 1. A. (Ed.). Studies in Functional Discourse Grammar. Bern: Peter Lang, 2005. p. 159-194.

HASELOW, A. A processual view on grammar: macrogrammar and the final field in spoken syntax. Language Sciences, v. 54, p. 77-101, 2016. DOI: 10.1016/j.langsci.2015.12.001.

HEINE, B.; KALTENBÖCK, G.; KUTEVA, T.; LONG, H. An outline of Discourse Grammar. In: BISCHOFF, S.; JANY, C. (Ed.). Functional approaches to language. Berlin: Mouton de Gruyter, 2013. p. 155-206. DOI: 10.1515/9783110285321.155.

HENGEVELD, K. A new approach to clausal constituent order. In: MACKENZIE, J. L;; OLBERTZ, H. (Ed.). Casebook in Functional Discourse Grammar. Amsterdam: John Benjamins, 2013. p. 15-38. DOI: 10.1075/slcs.137.02hen.

HENGEVELD, K.; KEIZER, E. Non-straightforward communication. Journal of Pragmatics, v. 43, n. 7, p. 1962-1976, 2011. DOI: 10.1016/j.pragma.2011.01.001.

HENGEVELD, K.; MACKENZIE, J. L. Functional Discourse Grammar: a typologically-based theory of language structure. Oxford: Oxford University Press, 2008. 528p. DOI: 10.1093/acprof:oso/9780199278107.001.0001.

HUDDLESTON, R.; PAYNE, J.; PETERSON, P. Coordination and supplementation. In: HUDDLESTON, R.; PULLUM, G. K. (Ed.). The Cambridge grammar of the English language. Cambridge: Cambridge University Press, 2002. p. 1273-1362. DOI: 10.1017/9781316423530.016.

KALTENBÖCK, G. Spoken parenthetical clauses in English: a taxonomy. In: DEHÉ, N.; KAVALOVA, Y. (Ed.). Parentheticals. Amsterdam: John Benjamins, 2007. p. 25-52. DOI: 10.1075/la.106.05kal.

KALTENBÖCK, G.; HEINE, B.; KUTEVA, T. On Thetical Grammar. Studies in Language, v. 35, n. 4, p. 848-893, 2011 DOI: $10.1075 /$ sl.35.4.03kal.

KEIZER, E. A Functional Discourse Grammar for English. Oxford: Oxford University Press, 2015. 360p.

KEIZER, E. Interpersonal adverbs in FDG: the case of frankly. In: KEIZER, E.; OLBERTZ, H. (Ed.). Recent developments in Functional Discourse Grammar. Amsterdam: John Benjamins, 2018. p. 48-88. DOI: 10.1075/slcs.205.03kei. 


\section{REVISTA DA ABRALIN}

KEIZER, E. The placement of extra-clausal constituents in Functional Discourse Grammar. Revista Canaria de Estudios Ingleses, La Laguna, v. 80, p. 89-121, 2020a. DOI: 10.25145/j.recaesin.2020.80.06.

KEIZER, E. The semantics, syntax and prosody of adverbs in English: an FDG perspective. In: KALTENBÖCK, G.; HASELOW, A. (Ed.). Grammar and cognition: dualistic models of language structure and language processing. Amsterdam: John Benjamins, 2020b, p. 191-231. DOI: https://doi.org/10.1075/hcp.70.06kei.

KROON, C. Discourse particles in Latin. Amsterdam: Gieben, 1995. 412p. DOI: 10.1163/9789004408999.

PAUL, W.; WHITMAN, J. Topic prominence. In: EVERAERT, M.; VAN RIEMSDIJK, H. C. (Ed.). The Wiley Blackwell companion to syntax, volume 8. Oxford: Wiley-Blackwell, 2017. p. 4473-4504. Available at: https://ling.auf.net/lingbuzz/002399. Accessed on: 02 October 2020.

POTTS, C. The logic of conventional implicatures. Oxford: Oxford University Press, 2005. 259p. DOI: 10.1093/acprof:oso/9780199273829.001.0001.

PULLUM, G. K.; HUDDLESTON, R. Adjectives and adverbs. In: HUDDLESTON, R.; PULLUM, G. K. (Ed.). The Cambridge grammar of the English language. Cambridge: Cambridge University Press, 2002. p. 525-595. DOI: 10.1017/9781316423530.0072002.

QUIRK, R.; GREENBAUM, S.; LEECH, G.; SVARTVIK, J. A comprehensive grammar of the English language. London: Longman, 1985. 1779p.

TESNIÈRE, L. Eléments de syntaxe structurale. 2. ed. Paris: Klincksieck, 1976. 674p. 